\title{
A retrospective study of dogs with vertebral lytic lesions diagnosed tomografically: 28 cases (2012-2017)
}

\section{Estudo retrospectivo de cães com lesões líticas vertebrais diagnosticadas tomograficamente: 28 casos (2012-2017)}

\author{
Gabriela Ribas Mendes ${ }^{1}$; Fernando Swiech Bach ${ }^{2}$; Luiz Fernando Cardoso Garcia'; \\ Saulo Henrique Weber ${ }^{3}$; José Ademar Villanova Junior ${ }^{3 *}$
}

\begin{abstract}
Lytic vertebral lesions cause significant pain and variable neurological deficits can cause sensory, motor and proprioceptive loss, and are causes of bones lysis such as discospondylitis, vertebral tumors, bone cysts and osteomyelitis. This study aimed to investigate the prevalence of vertebral lytic lesions in the canine population, from computed tomographic (CT) image analyses. A retrospective study, based on the descriptive findings from simple and contrast enhanced CT scans of dogs, between the years 2012 to 2017, was performed. The study consisted of the sequential analysis of 371 reports to identify vertebral lytic lesions, in areas with osteopenia and hypoattenuation, based on Hounsfield Unit scores. The Fisher's exact test and descriptive statistics were used for statistical analyses. Twentyeight cases $(7.54 \%)$ of vertebral lytic lesion were observed; $46.42 \%$ of these had characteristics of discospondylitis, with a prevalence in males, in the cranial and caudal ends of the vertebrae. Vertebral tumors were identified in $37.71 \%$ of the cases, with a higher incidence in defined medium sized breeds, with unifocal lesions in the vertebral body. Single lesion bone cysts were observed in $10.71 \%$ of cases and osteomyelitis in $7.14 \%$ of cases. A significant association between the number of vertebrae and degree of impairment (unifocal or multifocal) was observed. CT imaging has become a useful tool for evaluating the architecture and vertebral bone density. This study provides perspectives for the analysis of vertebral lytic lesions. In addition to showing the prevalence of lytic lesions, this study emphasizes the importance of using advanced diagnostic imaging techniques, such as CT imaging, for observing and identifying such lesions, thus directing further examinations such as bone biopsy, culture, and antibiogram or histopathology. It can be concluded that lytic lesions have a considerable incidence, impair the architecture of the vertebra and CT imaging is an effective tool for diagnosing them. Prevalence was observed in male dogs, neutered, with defined breed, of medium size, with unifocal lesion and lytic lesions associated with the discspondylitis.
\end{abstract}

Key words: Bone diseases. Computed tomography. Dogs. Osteopenia. Spine.

\section{Resumo}

Lesões líticas vertebrais causam dor significativa e déficits neurológicos variáveis, podem causar perda sensitiva, motora e proprioceptiva, são causas de lise óssea as discoespondilites, tumores vertebrais, cistos ósseos, osteomielites, entre outras. O presente estudo objetiva analisar a prevalência de

1 Discentes, Curso de Medicina Veterinária, Pontifícia Universidade Católica do Paraná, PUCPR, Curitiba, PR, Brasil gabriela. ribasmendes@gmail.com; fgtc@outlook.com

2 Discente, Programa de Pós-Graduação em Ciência Animal, PUCPR, Curitiba, PR, Brasil. E-mail: fernandosbach@yahoo.com

3 Profs., Programa de Pós-Graduação em Ciência Animal, PUCPR, Curitiba, PR, Brasil. E-mail: saulo.weber@pucpr; jose. villanova@pucpr.br

* Author for correspondence 
lesões líticas vertebrais na população canina a partir de achados tomográficos. Foi realizado estudo retrospectivo a partir dos achados descritivos de exames tomográficos simples e contrastados da coluna vertebral de cães, entre os anos de 2012 a 2017. Consistiu na análise sequencial de 371 laudos a fim de encontrar lesões líticas vertebrais, foram consideradas como líticas, áreas com osteopenia e área hipoatenuante seguida da Unidade Hounsfield inferior da vértebra sadia. Tratamento estatístico baseado no teste de Fisher e estatística descritiva. Foram observados 28 casos (7,54\%) de lesões líticas vertebrais, estas tinham características de discoespondilite em $46,42 \%$ dos casos, com prevalência de machos e acometimento em extremidades craniais e caudais das vértebras, seguido de tumores vertebrais em $37,71 \%$ dos casos, com maior incidência em raças definidas, de porte médio e lesão unifocal em corpo vertebral; em menores números, foram observados cistos ósseos $(10,71 \%)$ originando uma única lesão e osteomielites $(7,14 \%)$. Estatisticamente foi observado que há apenas dependência entre as variáveis - número de vértebras e grau de comprometimento (focal e multifocal). A tomografia computadorizada é boa opção de avaliação da arquitetura e densidade óssea vertebral. Esse estudo além de mostrar a descrição e prevalência de lesões líticas no grupo de cães estudado, enaltece a importância do uso de técnicas avançadas de diagnóstico por imagem, como a tomografia computadorizada para observância e identificação de tais lesões, algumas alterações são tipicamente observadas e servem de guia para o planejamento de mais exames como biópsia óssea seguida de cultura e antibiograma e/ou histopatologia. Pode-se concluir que lesões líticas têm incidência considerável, prejudicam a arquitetura da vértebra, e a tomografia computadorizada mostra-se como uma ótima ferramenta para diagnóstico deste distúrbio. Percebeu-se prevalência em cães do sexo masculino, castrados, com raça definida, de porte médio, com lesão unifocal e lesões líticas associadas à discoespondilites.

Palavras-chave: Doenças ósseas. Tomografia computadorizada. Cães. Osteopenia. Coluna Vertebral.

\section{Introduction}

Vertebral lytic lesions affect a significant portion of the canine population, cause pain and neurologic deficits (COSTA; COOK, 2016), are incapacitating (SIMMONS et al., 2015) and are associated with a risk of pathological fractures and spinal cord injury (CLEZARDIN; TETI, 2007; GUISE et al., 2006). Treatment is complex and difficult (BURKERT et al., 2005; RUOFF et al., 2017).

Due to their clinical relevance, lytic lesions are the presentation of several conditions. These conditions can be infectious, such as discoespondylitis (RUOFF et al., 2017) and vertebral osteomyelitis (CSÉBI et al., 2010); neoplastic, such as lymphoma, osteosarcoma (OSA), condrosarcoma and multiple myeloma (WISE-MILESTONE et al., 2012; COSTA; COOK, 2016); or iatrogenic, such as thermal necrosis and/or premature implant laxity (KOEHLER et al., 2005), and bone cysts (LOWRIE et al., 2014).

The preferred examination to observe the bony structures of the spine is computed tomography
(CT) imaging (COSTA; COOK, 2016) as it shows the reactive bone (TINS et al., 2007). Visualization of lytic lesions are challenging for both human and veterinary medicine. A recently published study reviewed 241 cytology samples from human patients with lytic bone lesions and concluded that fine-needle aspiration is a reliable tool for bone lesion diagnosis (SHERGILL et al., 2017). As far as we know, there are no specific studies on the prevalence of vertebral lytic lesions in dogs.

The present study describes and analyzes the prevalence of the most common vertebral lytic lesions in the canine population, from tomographic findings.

\section{Materials and Methods}

\section{Data Collection}

This retrospective study, which covered the period January 2012 to December 2017, was carried out in the diagnostic imaging department of Clinivet Veterinary Hospital, Curitiba-PR, Brazil. CT 
reports details were accessed by the DoctorVET ${ }^{\circledR}$ management system, allowing the collection of data inclusion criteria based on the selection of tomographic reports, standardization of the lesion and criteria for defining the etiology. We observed age, breed, size, sex, and reproductive state affected by vertebral lytic lesions, whether in pedicules, spinal processes, or vertebral bodies. The intervertebral space was also observed. Evidence of the condition was based on the tomographic descriptive report. There was no manipulation of any animal or tomographic images during data collection, or at any other time during this study. For all the descriptions accessed, the tomography examination equipment was always the same, from the Siemens mark, model Somatom Spirit Multi Slice.

The standard technique for examination was in the ventral decubitus position, at $100 \mathrm{kV}, 200$ $\mathrm{mA}$, and varying image thickness $(1.3,2$ and 3 $\mathrm{mm}$ ) depending on the size of the dog. Transverse, sagittal, and dorsal reconstructions were performed.

All examination interpretations were performed by one experienced veterinarian, who is an active member of the Brazilian Association of Veterinary Neurology (ABNV).

\section{Selection of tomographic reports}

Tomographic reports were identified and interpreted by two of the authors of this article (GRM and FSB). This consisted of the sequential analysis of 371 reports of animals submitted for the evaluation of possible spinal cord disorders, with and without the radiological contrast medium Iohexol (Omnipaque ${ }^{\mathrm{TM}}$ ), via intrathecal administration in the lumbar subarachnoid and/or cisterna magna space.

\section{Standardization}

Two types of reports were considered and identified as suggestive of lytic lesions: those with an area of vertebral bone destruction and osteopenia and/or hypoattenuating area followed by HU (Hounsfield unit) numerical values lower than those considered normal for vertebral bone density. For the cortical vertebral body $+1000 \mathrm{HU}$ was considered normal (TOBIAS; JIMMY, 2013) and for the medullary vertebral body, $133 \pm 37 \mathrm{HU}$ was considered acceptable (SCHREIBER et al., 2014).

\section{Etiology criteria}

Each descriptive report of the tomographic image, suggestive of lytic lesion, was classified with its possible causes. Reports in which the descriptive tomographic impression presented a lytic and proliferative lesion, located in the center of the intervertebral space with involvement of the articular faces, were classified as discospondylitis. Reports describing a lytic and proliferative lesion located in the vertebra with aggressive bone lesion were classified as vertebral tumor. Reports describing cavity image (well delimited and unique), with no evidence of aggressive growth, were classified as bone cyst and osteomyelitis due to gnawed bone, with confluence of the lithic areas and without involvement of the intervertebral discs (WEISBRODE, 2009; WIDMER; THRALL, 2013; COSTA, 2017).

\section{Statistical analyses}

Data were organized using Microsoft Excel (2016 version). Fisher's exact test was applied to the treatment of associations between two variables concerning size and degree of impairment - unifocal or multifocal, size and number of affected vertebrae (95\% CI), and number of affected vertebrae and degree of commitment (using SPSS Statistics ${ }^{\circledR}$ ). In addition, descriptive statistics were used to evaluate the clinical data regarding the baseline characteristics of the animals, such as identification of the vertebra and anatomic region affected by lytic lesions. 


\section{Results}

Twenty-eight dogs (7.54\%) presented tomographic findings of vertebral lytic lesions. Therefore, the majority of the animals (92.46\%) did not present vertebral alterations that were considered as lytic.

Most dogs (15/28, 53.57\%) with vertebral lytic lesions were of a defined breed, but there was no significant prevalence in any of them. As for the size of the breed, the majority were medium sized $(18 / 28,64.28 \%)$, followed by large $(9 / 28,32.21 \%)$ and small $(1 / 28,3.57 \%)$, and no lesions were observed in giant dogs.

Male dogs were the most affected (19/28, $67.85 \%$ ). Ages ranged from 2 to 14.11 years (mean 10.22 years). Considering the reproductive status, a higher incidence was observed in neutered animals $(15 / 28,53.57 \%)$, but considering both sex and reproductive status, there was a higher incidence in castrated males $(10 / 28,35.71 \%)$, followed by intact males $(9 / 28,32.21 \%)$, neutered females $(5 / 28$, $17.85 \%)$, and intact females $(4 / 28,14.28 \%)$.

With regard to exposure of the vertebral lytic lesions, the degrees of impairment were $78.57 \%$ $(22 / 28)$ unifocal for $21,42 \%(6 / 28)$ multifocal.

The individual characteristics of the animals, number of vertebrae involved, vertebral segment involved, and degree of impairment (focal or multifocal) for the probable causes of the lytic lesions observed are described in Tables 1 to 4 .

The number of tomographic images suggestive of lytic lesions associated with discospondylitis were significant in this retrospective study, representing $46.42 \%$ (13/28) of the descriptive reports. The majority were male $(10 / 28,35.71 \%)$, of which five were intact males and five were castrated. Two were intact females and one was neutered. The mean age was 8.89 years (range 2-14 years). There was a predominance for animals with no defined breed (9/13, 69.23\%).

Lagged tomographic exposition of all animals with images associated with discoespondylitis $(13 / 13,100 \%)$ showed the involvement of the caudal/ cranial end of the vertebral body, without a specific preference for a given region (Figure 1) A unifocal lesion was defined as the presence of only one lytic lesion between the vertebrae $(8 / 13,61.53 \%)$, and a multifocal lesion was defined as the presence of more than one vertebral lesion $(5 / 13,38.46 \%)$ (Table 1).

Tomographic images suggestive of lytic lesions associated with vertebral tumors (Figure 2) were present in $37.71 \%(10 / 28)$ of the cases, with a higher occurrence in females $(6 / 10,60 \%)$, four of which were neutered and two were intact. All males were castrated. Mean age was 10.9 years (range 4-14.11 years). There was a predominance for animals with defined breeds $(8 / 10,80 \%)$.

Figure 1. Sagittal and transverse sections of computed tomography images of the canine intervertebral disc region. Note the presence of lytic and proliferative lesions, located in the centers of the intervertebral spaces (arrows) with involvement of the articular faces, lesions suggestive of discospondylitis. The green line present in the sagittal cut corresponds to the cut-off point of the transverse tomographic image.

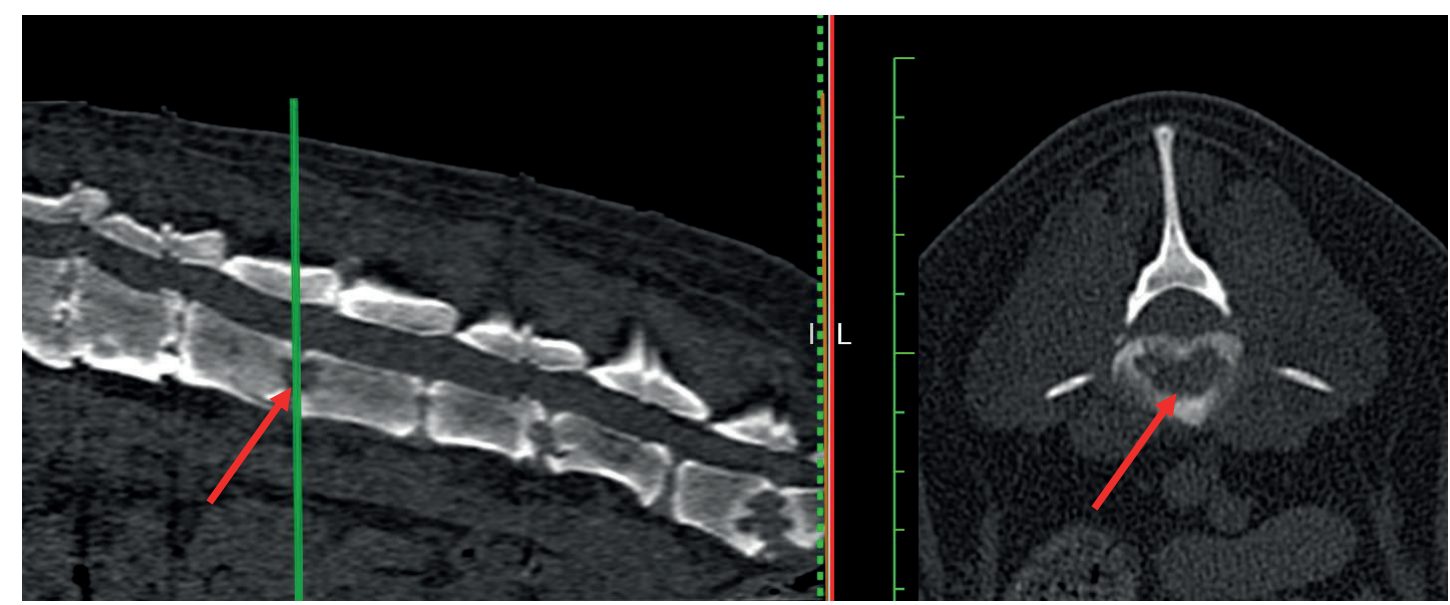


Table 1. Results of the epidemiological and tomographic findings of 13 dogs with lytic lesions on articular faces, suggestive of discospondylitis, in a retrospective study from 2012 to 2017.

\begin{tabular}{|c|c|c|c|c|}
\hline Individual characteristics & $\begin{array}{c}\mathrm{N}^{\circ} \text { of } \\
\text { vertebrae }\end{array}$ & $\begin{array}{l}\text { Spinal segment } \\
\text { involved }\end{array}$ & Anatomic region affected & Focus \\
\hline $\begin{array}{l}\text { MBD; m; male; } 2 \text { years; } \\
\text { castrated }\end{array}$ & 2 & T12-T13-L1 & $\begin{array}{l}\text { Caudal and cranial extremity of } \\
\text { vertebral body }\end{array}$ & Multifocal \\
\hline $\begin{array}{l}\text { MBD; m; male; } 12 \text { years; } \\
\text { castrated }\end{array}$ & 1 & L2-L3 & $\begin{array}{c}\text { Caudal and cranial extremity of } \\
\text { vertebral body }\end{array}$ & Unifocal \\
\hline $\begin{array}{l}\text { MBD; m; male; } 12,1 \text { years; } \\
\text { castrated }\end{array}$ & 1 & C7-T1 & $\begin{array}{c}\text { Caudal and cranial extremity of } \\
\text { vertebral body }\end{array}$ & Unifocal \\
\hline $\begin{array}{l}\text { German Shepherd; g; } \\
\text { female; 7,6 years; castrated }\end{array}$ & 1 & $\mathrm{~T} 5-\mathrm{T} 6$ & $\begin{array}{c}\text { Caudal and cranial extremity of } \\
\text { vertebral body }\end{array}$ & Unifocal \\
\hline $\begin{array}{l}\text { MBD; m; male; } 7,1 \text { years; } \\
\text { not castrated }\end{array}$ & 3 & $\begin{array}{l}\text { T12-T13; L1-L2; } \\
\text { L5-L6 }\end{array}$ & $\begin{array}{l}\text { Caudal and cranial extremity of } \\
\text { vertebral body }\end{array}$ & Multifocal \\
\hline $\begin{array}{l}\text { Sharpei; g; male } 3 \text { years; } \\
\text { castrated }\end{array}$ & 1 & L7-S1 & $\begin{array}{c}\text { Caudal and cranial extremity of } \\
\text { vertebral body }\end{array}$ & Unifocal \\
\hline $\begin{array}{l}\text { MBD; m; female; } 11,9 \\
\text { years; not castrated }\end{array}$ & 1 & C6-C7 & $\begin{array}{c}\text { Caudal and cranial extremity of } \\
\text { vertebral body }\end{array}$ & Unifocal \\
\hline $\begin{array}{l}\text { MBD; m; female; } 12,2 \\
\text { years; not castrated }\end{array}$ & 1 & $\mathrm{C} 6-\mathrm{C} 7$ & Caudal extremity of vertebral body & Unifocal \\
\hline $\begin{array}{l}\text { German Shepherd; g; male; } \\
14 \text { years; not castrated }\end{array}$ & 2 & L1-L2; L3-L4 & $\begin{array}{c}\text { Caudal and cranial extremity of } \\
\text { vertebral body }\end{array}$ & Multifocal \\
\hline $\begin{array}{l}\text { MBD; m; male; } 8,5 \text { years; } \\
\text { not castrated }\end{array}$ & 4 & $\begin{array}{l}\text { T12-T13; L1-L2; } \\
\text { L2-L3; L5-L6 }\end{array}$ & $\begin{array}{c}\text { Caudal and cranial extremity of } \\
\text { vertebral body }\end{array}$ & Multifocal \\
\hline $\begin{array}{l}\text { Lhasa Apso; m; male; } 10,7 \\
\text { years; not castrated }\end{array}$ & 1 & $\mathrm{C} 6-\mathrm{C} 7$ & $\begin{array}{c}\text { Caudal and cranial extremity of } \\
\text { vertebral body }\end{array}$ & Unifocal \\
\hline $\begin{array}{l}\text { MBD; m; male; } 7,6 \text { years; } \\
\text { not castrated }\end{array}$ & 4 & $\begin{array}{c}\text { T12-T13;L1- } \\
\text { L2;L2-L3;L5-L6 }\end{array}$ & $\begin{array}{c}\text { Caudal and cranial extremity of } \\
\text { vertebral body }\end{array}$ & Multifocal \\
\hline $\begin{array}{l}\text { MBD; m; male; } 10 \text { years; } \\
\text { castrated }\end{array}$ & 1 & $\mathrm{C} 4-\mathrm{C} 5$ & $\begin{array}{c}\text { Caudal and cranial extremity of } \\
\text { vertebral body }\end{array}$ & Unifocal \\
\hline
\end{tabular}

MBD: mixed breed dog; m: medium size; g: giant size; C: cervical vertebra; T: thoracic vertebra; L: lumbar vertebra.

Figure 2. Sagittal cut of computed tomography image in dog vertebral column. Note the presence of lytic, proliferative and aggressive lesion (arrow) located in vertebral body (T13), suggestive of vertebral tumor.

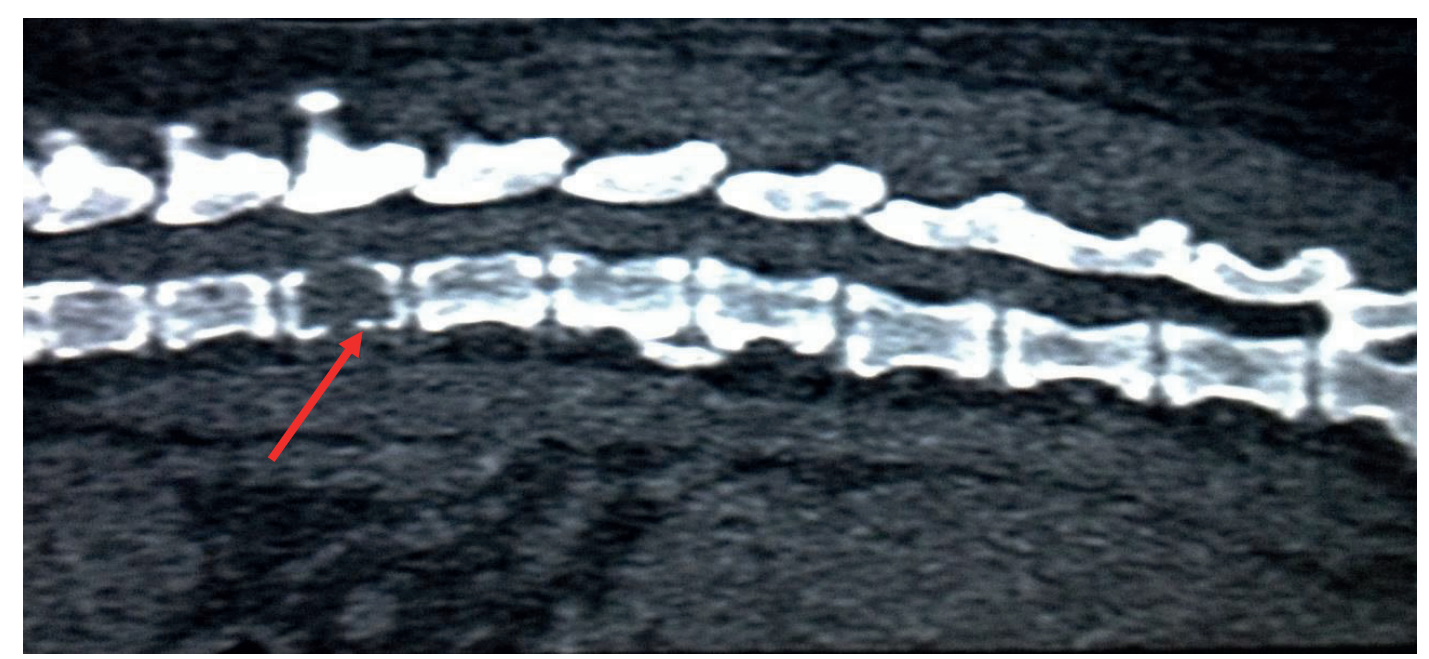

Semina: Ciências Agrárias, Londrina, v. 40, n. 5, suplemento 1, p. 2223-2234, 2019 
As deduced from the tomographic descriptive reports, vertebral body was the prevailing site of lithic lesions, suggestive of vertebral tumors, in 50\% (5/10) of cases. Lytic lesions were also observed in other vertebral anatomical regions, such as the articular, spinous and transverse processes, and the dorsal and lateral laminas, although all involved the vertebral body. Lesions were observed in cervical (2), thoracic (2), lumbar (5) and thoracic regions, in addition to lumbar (1) (Table 2).

Table 2. Results of the epidemiological and tomographic findings of the 10 dogs with lytic lesions, suggestive of vertebral tumor, in a retrospective study from 2012 to 2017.

\begin{tabular}{|c|c|c|c|c|}
\hline Individual characteristics & $\begin{array}{c}\mathrm{N}^{\circ} \text { of } \\
\text { vertebrae }\end{array}$ & $\begin{array}{l}\text { Spinal segment } \\
\text { involved }\end{array}$ & Anatomic region affected & Focus \\
\hline $\begin{array}{l}\text { Golden retriever; g; female; } \\
13 \text { years; castrated }\end{array}$ & 1 & $\mathrm{~T} 10$ & Body; Left dorsal lamina & Unifocal \\
\hline $\begin{array}{l}\text { MBD; m; male; } 11 \text { years; } \\
\text { castrated }\end{array}$ & 1 & $\mathrm{C} 4$ & Body & Unifocal \\
\hline $\begin{array}{l}\text { Rottweiler; g; male; } 11 \\
\text { years; castrated }\end{array}$ & 1 & L7 & Body; Spinous process & Unifocal \\
\hline $\begin{array}{l}\text { Scottish terrier; m; male; } 9 \\
\text { years; castrated }\end{array}$ & 1 & L5 & Body & Unifocal \\
\hline $\begin{array}{l}\text { Yorkshire terrier; s; female; } \\
11,1 \text { years; castrated }\end{array}$ & 1 & L7 & Body & Unifocal \\
\hline $\begin{array}{l}\text { Pit Bull terrier; m; female; } \\
11 \text { years; castrated }\end{array}$ & 1 & L3 & Body; Articular and spinous process & Unifocal \\
\hline $\begin{array}{l}\text { Pointer; g; male; } 4 \text { years; } \\
\text { castrated }\end{array}$ & 1 & L2 & Body & Unifocal \\
\hline $\begin{array}{l}\text { MBD; m; female; } 13,7 \\
\text { years; castrated }\end{array}$ & 1 & $\mathrm{C} 4$ & $\begin{array}{l}\text { Body; Right dorsal lamina; Articular } \\
\text { and transverse process }\end{array}$ & Unifocal \\
\hline $\begin{array}{l}\text { Dachshund; m; female; } \\
14,11 \text { years; not castrated }\end{array}$ & 7 & $\begin{array}{c}\text { T7-T8-T9; } \\
\text { T11; L3-L4; L6 }\end{array}$ & $\begin{array}{l}\text { Body; Left and right laminas; } \\
\text { Spinous process }\end{array}$ & Multifocal \\
\hline $\begin{array}{l}\text { English Bulldog; g; female; } \\
\text { 11,1 years; not castrated }\end{array}$ & 1 & $\mathrm{~T} 7$ & Body & Unifocal \\
\hline
\end{tabular}

MBD: mixed breed dog; s: small size; m: medium size; g: giant size; C: cervical vertebra; T: thoracic vertebra; L: lumbar vertebra.

The tomographic images suggestive of lytic lesions associated with bone cysts (Figure 3) were present in $10.71 \%(3 / 28)$ of the reports, exclusively in male dogs, two of which were intact and one was neutered. The mean age was 12.10 years (range 9.413.9 years). There was a predominance of defined races at $66.66 \%(2 / 3)$. The tomographic descriptions reported that $100 \%$ were unifocal with $66.66 \%(2 / 3)$ in articular faces and $33.33 \%(1 / 3)$ in the vertebral body, of thoracic vertebrae (2) and lumbar vertebra (1) (Table 3). 
Figure 3. Cross sections of cystic lesions (smaller arrows), with respective values of Hounsfield units (-62.1 and -102.5) (larger arrows). Note the presence of lithic and cavitary images, without evidence of aggressive growth, suggestive of bone cysts.

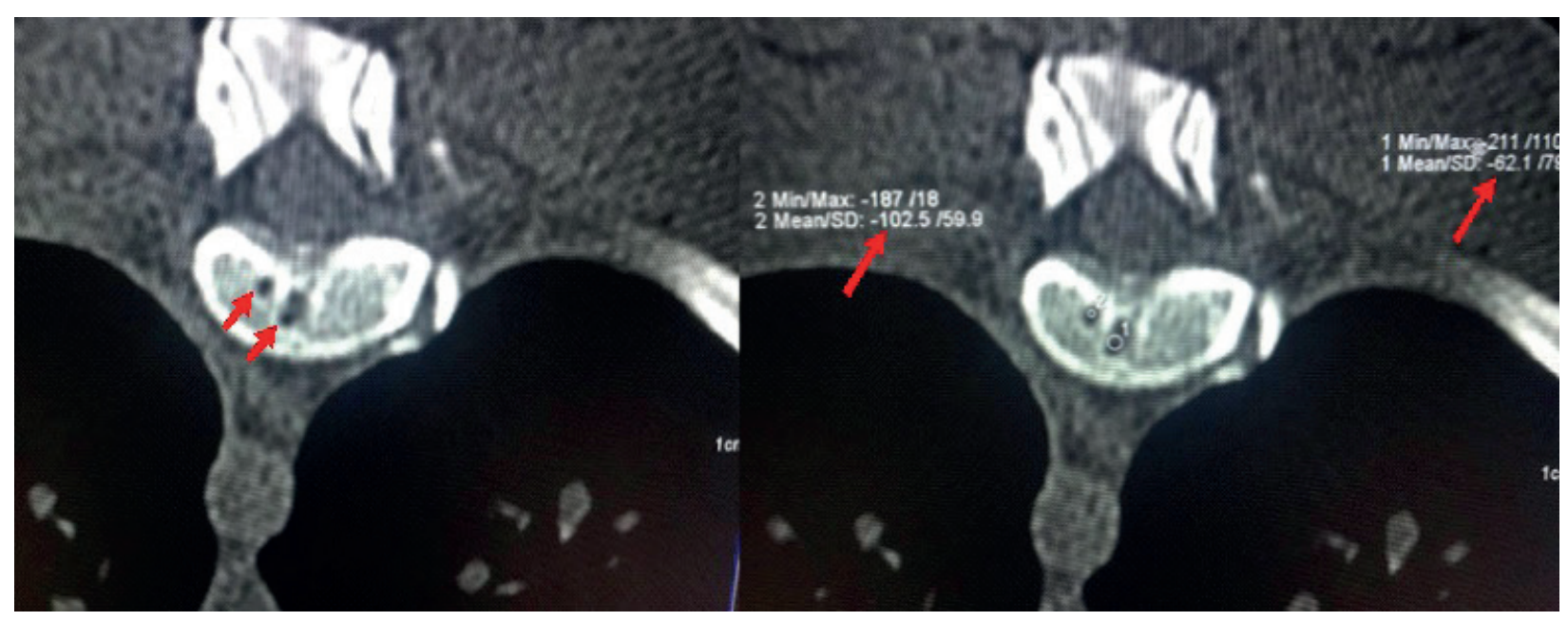

Table 3. Results of the epidemiological and tomographic findings of three dogs with lytic lesions, suggestive of bone cysts, in a retrospective study from 2012 to 2017.

\begin{tabular}{lcccc}
\hline Individual characteristics & $\begin{array}{c}\mathrm{N}^{\circ} \text { of } \\
\text { vertebrae }\end{array}$ & $\begin{array}{c}\text { Spinal segment } \\
\text { involved }\end{array}$ & Anatomic region affected & Focus \\
\hline $\begin{array}{l}\text { Dachshund; m; male; } 13 \\
\text { years; castrated }\end{array}$ & 1 & L6 & $\begin{array}{c}\text { Caudal extremity of } \\
\text { vertebral body }\end{array}$ & Unifocal \\
$\begin{array}{l}\text { Dalmatian; g; male; } 13,9 \\
\text { years; not castrated }\end{array}$ & 1 & T4 & Body & Unifocal \\
$\begin{array}{l}\text { MBD; m; male; } 9,4 \text { years; } \\
\text { not castrated }\end{array}$ & 1 & T12 & $\begin{array}{c}\text { Caudal extremity of } \\
\text { vertebral body }\end{array}$ & Unifocal \\
\hline
\end{tabular}

MBD: mixed breed dog; m: medium size; g: giant size; T: thoracic vertebra; L: lumbar vertebra.

The tomographic images suggestive of lytic lesions associated with osteomyelitis were present in $7.14 \%(2 / 28)$ of cases; these were both intact male dogs. The mean age was 11.1 years (range 9.7-12.5 years). There was no prevalence of breed and one was undefined. In the descriptive report, the osteomyelitis affected the dorsal blade and the cranial and caudal extremities of the vertebral bodies, all occurring in the lumbar vertebrae (Table 4).

There was no association between the size of the animals with the degree of impairment and the number of vertebrae affected (Fisher's exact test). 
Table 4. Results of the epidemiological and tomographic findings of two dogs with lytic lesions, suggestive of osteomyelitis, in a retrospective study from 2012 to 2017.

\begin{tabular}{lcccc}
\hline Individual characteristics & $\begin{array}{c}\mathrm{N}^{0} \text { of } \\
\text { vertebrae }\end{array}$ & $\begin{array}{c}\text { Spinal segment } \\
\text { involved }\end{array}$ & Anatomic region affected & Focus \\
\hline $\begin{array}{l}\text { MBD; m; male; 12,5 years; } \\
\text { not castrated }\end{array}$ & 1 & L5 & Dorsal lamina & Unifocal \\
$\begin{array}{l}\text { Old English Sheepdog; g; } \\
\text { male; } 9,7 \text { years; not castrated }\end{array}$ & 1 & L7-S1 & $\begin{array}{c}\text { Caudal and cranial extremity } \\
\text { of vertebral body }\end{array}$ & Unifocal \\
\hline
\end{tabular}

MBD: mixed breed dog; m: medium size; g: giant size; L: lumbar vertebra; S: sacral vertebra.

\section{Discussion}

This study identified that, of the 371 reports of tomographic examinations performed in the vertebral column, 28 of them $(7.54 \%)$ represented vertebral lytic lesions. In CT images that suggest specific etiology that may or may not involve the spinal cord, it should be remembered that more than one disease may be active in the same site (WEISBRODE, 2009).

A definitive diagnosis, by means of microbiological or histopathological examinations, was not the objective of this study. Tomographic images were suggestive of discospondylitis, neoplasia, bone cyst and osteomyelitis, but did not reveal the etiology. Histopathological examinations, cultures of biological materials and tomographic images were not correlated in this study. We acknowledge the importance of these considerations and suggest such analyses in future studies, However, this does not undermine the value of our study, as some factors are typically observed and their descriptions are reported in different text books (WEISBRODE, 2009; WIDMER; THRALL, 2013; COSTA, 2016).

Although relevant, the search for etiological factors through laboratory analysis is not always easy to obtain. A study by Garg et al., (2014) shows that CT-guided percutaneous biopsies are not efficient for identifying microorganisms that cause vertebral osteomyelitis as only $19.0 \%$ of biopsy cases were positive, further reinforcing the findings of Sehn and Gilula (2012), where only $30 \%$ of the samples were positive. Pathogens might be difficult to grow and require several weeks for isolation (CHEW; KLINE, 2001; GARG et al., 2014). In contrast, another study demonstrated that CT-guided biopsies for vertebral neoplasms have $100 \%$ sensitivity and efficiency (GARG et al., 2016).

The fact that the dogs' size is not related to the degree of impairment and to the number of vertebrae affected, is predominantly due to the predominance of lytic lesions suggestive of discospondylitis followed by lithic lesions suggestive of neoplasias, such affections reach different sizes, races and age groups (BURKERT et al., 2005; COSTA; COOK, 2016).

The highest incidence of lytic lesions was in male dogs, neutered, with defined breed, of medium size. However, these factors are not closely related to the insurgency of lytic lesions. Therefore, the predominant population is largely heterogeneous.

All cases of discospondylitis in this study promoted lytic lesion at the caudal/cranial extremities of the vertebral body. This corroborates previous research, which shows that disc diseases such as discospondylitis are precursors of vertebral lytic lesions (BURKERT et al., 2005; RUOFF et al., 2017). Ruoff et al. (2017) cite a high prevalence of this disease in male dogs, roughly twice that of females, also in agreement with our study.

The mean age of the animals affected in this study was 8.89 years, ranging from two to 14 years. This supports previous research showing the average age of affected dogs varies between 4.1 and 9 years 
(DAVIS et al., 2010). Any area of the spine can be affected by discospondylitis and consequently generate lytic lesions at the vertebral extremities.

In analyzing the location of the lytic lesions associated with discospondylitis, it was noted that there was a predominance of unifocal lesions without predisposition for the vertebral segment. However, thoracolumbar and lumbosacral lesions are more common than lesions in the cervical spine, and multiple lesions are also found (BURKERT et al., 2005). This predilection for more caudal segments may be due to septic migration originating from genitourinary infections, whereby bacteria enter the vertebral bodies through the bloodstream (RUOFF et al., 2017). According to Burkert et al. (2005), these lytic lesions have a lower incidence in cervical vertebrae, but not in the cervicothoracic region. As shown by CT, osteolysis of the adjacent vertebral extremities can occur with or without invasion to the vertebral body (GONZALO-ORDEN et al., 2000; RUOFF et al., 2017).

All the animals with images suggestive of vertebral neoplasms had involvement of the vertebral body, and may be explained by comparison with human studies, where neoplasia derives from the greater vascular supply and bone mass of the region (ARAÚJO et al., 2013). The vast majority of bone tumors in dogs are malignant (PLATT; OLBY, 2013).

Vertebral tumor lesions have a higher unifocal incidence, in agreement with Cheon et al., (2018), who observed that most hypoattenuating changes are solitary.

In our study, the prevalence of tumors in pure breeds was noted. This was also reported by Sapierzyński and Czopowicz (2017), who observed that purebred dogs were four times more likely to develop OSA than mixed-breed dogs The mean age agrees with Culp et al. (2014) where peak occurrences of OSA occur between seven and 10 years of age.
The superiority of dogs with bone tumors is this study agrees with the findings of Trost et al. (2014), who reported that females were more affected by vertebral tumors, possibly due to metastatic migration of breast tumors. For cystic lesions, the welldefined and hypoattenuating area, with a reduction in the HU count, was considered, in accordance with Cheon et al. (2018). Hypoattenuating vertebral bone alterations may be related to some infrequent lesions, such as cystic lesions and occurrences may cause clinical signs or occur as incidental findings (COSTA; COOK, 2016).

Factor that may lead to osteomyelitis include direct exposure of the vertebral bodies to pathogens introduced during surgery, or previous trauma (SEHN; GILLULA, 2012). Upon identification of the lytic lesion, histological and microbiological analyses remain the gold standard for diagnosis, enabling treatment that is specific for the causative pathogen (GARG et al., 2014).

We believe CT is a useful tool for assessing vertebral bone density and architecture, in accordance with the results of Lucas et al. (2017), where bone density measurement by CT (HU) correlated well with the results of DEXA (absorption of dual energy X-rays). Our study provides perspectives for the analysis of vertebral lytic lesions.

\section{Conclusion}

Lytic lesions have a considerable incidence and impair the architecture of the vertebrae; CT is a good diagnostic tool for the detection and characterization of lytic lesions. However, the degree of impairment and number of vertebrae are not influenced by the size of the animal. Prevalence was observed in medium sized, neutered males, of defined breed. Unifocal lytic lesions were associated with discospondylitis. However, these factors were not closely related to the prevalence of lytic lesions. Therefore, the predominant population is largely heterogeneous. 


\section{References}

ARAÚJO, J. L.; ESTEVES VEIGA, J. C.; FIGUEIREDO, E. G.; BARBOZA, V. R.; DANIEL, J. W.; PANAGOPOULOS, A. T. Management of metastatic spinal column neoplasms - an update. Revista Colégio Brasileiro de Cirurgiões, v. 40, n. 6, p. 508-513, 2013. DOI: $10.1590 / \mathrm{S} 0100-69912013000600015$

BURKERT, B. A.; KERWIN, S. C.; HOSGOOD, G. L.; PECHMAN, R. D.; FONTENELLE, J. P. Signalment and clinical features of diskospondylitis in dogs: 513 cases (1980-2001). Journals - American Veterinary Medical Association, v. 227, n. 2, p. 268-275, 2005. DOI: 10.2460/javma.2005.227.268

CHEON, B.; PARKS, S.; LEE, S. K.; CHO KO; CHOI, J. Variation of canine vertebral bone architecture in computed tomography. Journal of Veterinary Science, v. 19, n. 1, p. 145-150, 2018. DOI: 10.4142/ jvs.2018.19.1.145

CHEW, F. S.; KLINE, M. J. Diagnostic yield of CTguided percutaneous aspiration procedures in suspected spontaneous infectious diskitis. Radiology, v. 218, n. 1, p. 211-214,2001. DOI: 10.1148/radiology.218.1.r01ja06211

CLEZARDIN, P.; TETI, A. Bone metastasis: pathogenesis and therapeutic implications. Clinical \& Experimental Metastasis, v. 24, n. 8, p. 599-608, 2007. DOI: $10.1007 /$ s10585-007-9112-8

COSTA, R. C. da. Neoplasias intracranianas, espinais e de nervos periféricos. In: DALECK, C. R.; NARDI, A. B. B. de Oncologia em cães e gatos. 2. ed. Rio de Janeiro: Ed. Guanabara, 2016. p. 864-907.

COSTA, R. C. da. Princípios e aplicações da ressonância magnética. In: DEWEY, C. W.; COSTA, R. C. da. Neurologia canina e felina Guia prático. São Paulo: Ed. Guará. 2017. p. 108-167.

COSTA, R. C. da; COOK, L. B. Cystic abnormalities of the spinal cord and vertebral column. Veterinary Clinics of North America: Small Animal Practice, v. 46, n. 2, p. 277-293, 2016. DOI: 10.1016/j.cvsm.2015.10.010

CSÉBI, P.; JAKAB, C.; JÁNOSI, K.; SELLYEI, B.; IPOLYI, T.; SZABÓ, Z.; ARANY-TÓTH, A.; NÉMETH, $\mathrm{T}$. Vertebral osteomyelitis and meningomyelitis caused by pasteurella canis in a dog - clinicopathological case report. Acta Veterinaria Hungarica, v. 58, n. 4, p. 413421, 2010. DOI: 10.1556/AVet.58.2010.4.2

CULP, W. T.; OLEA-POPELKA, F.; SEFTON, J.; ALDRIDGE, C. F.; WITHROW, S. J.; LAFFERTY, M. H.; REBHUN, R. B.; KENT, M. S.; EHRHART, $\mathrm{N}$. Evaluation of outcome and prognostic factors for dogs living greater than one year after diagnosis of osteosarcoma: 90 cases (1997-2008). Journals American Veterinary Medical Association, v. 245, n. 10, p. 1141-1146, 2014. DOI: 10.2460/javma.245.10.1141

DAVIS, M. J.; DEWEY, C. W.; WALKER, M. A.; KERWIN, S. C.; MOON, M. L.; KORTZ, G.D.; KOBLIK, P. D.; MAHAFFEY, M. B.; BUDSBERG, S. C.; SLATER, M. R. Contrast radiographic findings in canine bacterial diskospondylitis: a multicenter retrospective study of 27 cases. Journal of the American Animal Hospital Association, v. 36, n. 1, p. 81-85, 2000. DOI: $10.5326 / 15473317-36-1-81$

GARG, V.; KOSMAS, C.; JOSAN, E. S. et al. Computed tomography-guided percutaneous biopsy for vertebral neoplasms: a department's experience and hybrid biopsy technique to improve yield. Neurosurgical Focus Journal of Neurosurgery, v. 41, p. E17, 2016. DOI: 10.3171/2016.4.FOCUS1614

GARG, V.; KOSMAS, C.; YOUNG, P. C.; TOGARU, U. K.; ROBBIN, M. R. Computed tomography-guided percutaneous biopsy for vertebral osteomyelitis: a department's experience. Neurosurgical Focus Journal of Neurosurgery, v. 37, n. 2, p. E10, 2014. DOI: 10.3171/2014.6.FOCUS14134

GONZALO-ORDEN, J. M.; ALTONAGA, J. R.; ORDEN, M. A. et al. Magnetic resonance, computed tomographic and radiologic findings in a dog with discospondylitis. Veterinary Radiology \& Ultrasound, v. 41 , n. 2 , p. $142-144$, 2000. DOI: $10.1111 /$ j.17408261.2000.tb01467.x

GUISE, T. A.; MOHAMMAD, K. S.; CLINES, G. et al. Basic mechanisms responsible for osteolytic and osteoblastic bone metastases. Clinical Cancer Research, v. 12 , n. 20 , p. 6213 s-6216s , 2006. DOI: $10.1158 / 1078-$ 0432.CCR-06-1007

KOEHLER, C. L; STOVER, S. M.; LECOUTEUR, R. A.; SCHULZ, K. S.; HAWKINS, D. A. Effect of a ventral slot procedure and of smooth or positive- profile threaded pins with polymethylmethacrylate fixation on intervertebral biomechanics at treated and adjacent canine cervical vertebral motion units. American Journal of Veterinary Research, v. 66, n. 4, p. 678-687, 2005. DOI: 10.2460/ajvr.2005.66.678

LOWRIE, M. L.; PLATT, S. R.; GAROSI, L. S. Extramedullary spinal cysts in dogs. Veterinary Surgery, v. 43, n. 6, p. 650-662, 2014. DOI: $10.1111 /$ j.1532950X.2014.12200.x

LUCAS, K.; BEHRENS, B. A; NOLTE, I.; GALINDOZAMORA, V.; BETANCUR, S.; ALMOHALLAMI, A.; BOUGUECHA, A.; MOSTAFA, A.; LERCH, M.; STUKENBORG-COLSMAN, C.; WEFSTAEDT, P. 
Comparative Investigation of Bone Mineral Density Using CT and DEXA in a Canine Femoral Model. Wiley Online Library, v. 35, n. 12, p. 2667-2672, 2017. DOI: $10.1002 /$ jor. 23574

PLATT, S., OLBY, N. J. Manual of canine and feline neurology. Gloucester: The British Small Animal Veterinary Association, 2013. 552 p.

RUOFF, C. M.; KERWIN, S. C.; TAYLOR, A. R. Diagnostic imaging of discospondylitis. Veterinary Clinics of North America: Small Animal Practice, v. 48, n. 1, p. 85-94, 2017. DOI: 10.1016/j.cvsm.2017.08.007

SAPIERZYŃSKI, R.; CZOPOWICZ, M. The animaldependent risk factors in canine osteosarcomas. Polish Journal of Veterinary Sciences, v. 20, n. 2, p. 293-298, 2017. DOI: $10.1515 /$ pjvs-2017-0035

SCHREIBER, J. J.; ANDERSON, P, A.; HSU, W. $\mathrm{K}$. Use of computed tomography for assessing bone mineral. Neurosurg Focus, v. 37, n. 1, p. 1-8, 2014. DOI: 10.3171/2014.5.FOCUS1483

SEHN, J. K.; GILULA, L. A. Percutaneous needle biopsy in diagnosis and identification of causative organisms in cases of suspected vertebral osteomyelitis. European Journal of Radiology, v. 81, n. 5, p. 940-946, 2012. DOI: 10.1016/j.ejrad.2011.01.125

SHERGILL, U.; VITKOVSKI, T.; STOFFELS, G. MELISSA, KLEIN, M.; GIMENEZ, C.; ALICE, L.; COCKER, R.; CHAU. K.; DAS, K. Fine-needle aspiration biopsy of lytic bone lesions: An institution's experience. Diagnostic Cytopathology, v. 45, n. 11, p. 989-997, 2017. DOI: 10.1002/dc.23807
SIMMONS, J. K.; HILDRETH, B. E.; SUPSAVHAD, W.; ELSHAFAE, S. M.; HASSAN, B. B.; DIRKSEN, W. P.; TORIBIO, R. E.; ROSOL, T. J. Animal models of bone metastasis. Veterinary Pathology, v. 52, n. 5, p. 827841, 2015. DOI: 10.1177/0300985815586223

TINS, B. J.; CASSAR-PULLICINO, V. N.; LALAM, R. K. Magnetic resonance imaging of spinal infection. Topics in Magnetic Resonance Imaging, v. 18, n. 3, p. 213-222, 2007. DOI: 10.1097/RMR.0b013e3180f60c3f

TOBIAS, S.; JIMMY, S. Veterinary computed tomography. Chichester: Wiley-Blackwell, 2013. p.211.

TROST, M. E.; INKELMANN, M. A.; GALIZA, G. J. Occurrence of tumours metastatic to bones and multicentric tumours with skeletal involvement in dogs. Journal of Comparative Pathology, v. 150, n. 1, p. 8-17, 2014. DOI: 10.1016/j.jcpa.2013.07.002

WEISBRODE, S. E. Osso e articulações. In: McGAVIN, M. D.; ZACHARY, J. F. Bases da patologia em veterinária. 4. ed. Rio de Janeiro: Elsevier/Mosby, 2009. p. 1041-1106.

WIDMER, W. R.; THRALL, D. E. Canine and feline vertebrae. In: THRALL, D. E. Textbook of veterinary diagnostic radiology. $6^{\text {th }}$ ed. Missouri: Elsevier/Mosby, 2013. p. 172-193.

WISE-MILESTONE, L.; AKENSA, M. K.; THUDIB, N.; ROSOLB, T.; HOJJAT, S. P.; GRYNPAS; M. D.; WHYNE, C. M. Evaluating the effects of mixed osteolytic/osteoblastic metastasis on vertebral bone quality in a new rat model. Journal of Orthopaedic Research, v. 30, n. 5, p. 817-823, 2012. DOI: 10.1002/ jor. 21577 
